\title{
Influence of Precipitating Agent Concentration on Nanoparticles Size and Magnetic Properties of Zinc Ferrites
}

\author{
ELENA VASILICA TRANDAFIR ${ }^{1 *}$, RADU CIOCARLAN ${ }^{2}$, AUREL PUI ${ }^{2}$, ROLF HEMPELMANN ${ }^{3}$, \\ OVIDIU FLORIN CALTUN ${ }^{1}$ \\ ${ }^{1}$ Alexandru Ioan Cuza University of Iasi, Faculty of Physics, 11 Blvd. Carol I, 700506, Iasi, Romania \\ ${ }^{2}$ Alexandru Ioan Cuza University of Iasi, Faculty of Chemistry, 11 Blvd. Carol I, 700506, Iasi, Romania \\ ${ }^{3}$ Physikalische Chemie, Universitaet des Saarlandes, Saarbruecken, Germany
}

\begin{abstract}
A series of Zn ferrite nanoparticles was prepared by varying the concentration of precipitating agent $(\mathrm{NaOH})$ in the range of $1-5 \mathrm{M}$. Carboxymethylcellulose (CMC) was used as capping agent for stabilizing the particles and to prevent agglomeration. The synthesis done at low temperature was followed by a thermal treatment at $500^{\circ} \mathrm{C}$ for $6 \mathrm{~h}$ in air. The crystallite size determined using Scherer formula ranged between 8 - $10 \mathrm{~nm}$ while the nanoparticles average size observed by Transmission Electron Microscopy varied in between 7-10 nm showing that the increase of coprecipitation agent concentration influences the particles growth. Vibrating sample magnetometry confirmed the strong influence that nanoparticles morphology and size play on superparamagnetic properties of $\mathrm{Zn}$ ferrite.
\end{abstract}

Keywords: zinc ferrite; nanoparticle; coprecipitation; NaOH concentration; X-Ray diffraction

New studies regarding zinc ferrites nanoparticles were developed for introducing the importance of small concentration of the precipitating agent during the synthesis step. In the last years $\mathrm{Zn}$ ferrite nanoparticles were reconsidered for different application such as hyperthermia [1], contrast agents [2 - 5], drug delivery [6], theranostic [7] due to their biocompatibility. Moreover this material is also being used for industrial application as waste water treatment [8], environmental protection [9] as well as gas sensing [10] and the list of possible application can continue.

In bulk $\mathrm{ZnFe}_{2} \mathrm{O}_{4}$ has a normal spinel structure, in which all $\mathrm{Zn}^{2+}$ ions occupy tetrahedral positions (A-sites) and all $\mathrm{Fe}^{3+}$ ions octahedral positions (B-sites) being paramagnetic at room temperature, the transition to a magnetically ordered state occurs only at temperatures of about $10 \mathrm{~K}$ [11]. Magnetic properties of spinel ferrite nanoparticles are different from those of bulk materials and substantially depend on the particle size [12], [13]. The magnetic properties change significantly when the particle size decreases to a few tens of nanometers because at this scale cations' inversion occurs, i.e. a part of zinc ions occupy the sites B, and part of iron ions the sites A [14] and the spinel structure become a mixed one and as consequence to the apparition of spontaneous magnetization [15]. Among the various preparation methods developed to produce $\mathrm{Zn}$ ferrite nanoparticles, such as reverse micelle [16], sol-gel [17], hydrothermal [11], the coprecipitation is the most used. A big part of literature reports the synthesis of ferrites from nitrate precursors [11, 18-29] but special attention is recently given to metallic chlorides precursors [30]-[40] due to the higher solubility in water of the resulted sodium chloride compared to the sodium nitrite $[32,33,37,38]$.

Depending on the synthesis media, aqueous or not, on the coprecipitation agent concentration or the $\mathrm{pH}$ of the solution or of the subsequent thermal treatment different grade of inversion is realized. The percentage of $\mathrm{Fe}$ ions in octahedral $\left(\mathrm{Fe}^{3+}\right)$ and tetrahedral $\left(\mathrm{Fe}^{2+}\right)$ sites varies and the magnetization of the two sub-lattice do not compensate and the nanoparticles behaves magnetic or superparamagnetic above room temperature. It is well known that the influence of the coprecipitation agent in the solution [41, 42] and the annealing treatment [38, 43-45] can influence dramatically the crystallite growth.

The main goal of our study was to prepare $\mathrm{ZnFe}_{2} \mathrm{O}_{4}$ capped nanoparticles by simple aqueous coprecipitation of zinc (II) chloride and ferric (III) chloride solutions using $\mathrm{NaOH}$ as alkali and carboxymethylcellulose (CMC) as surfactant $[34,37]$. By varying the concentration of $\mathrm{NaOH}$, we expect to impose a certain particle shape which can lead to different grain size and consequently better tuning of magnetic properties. The variations in particle size and shape induced predominant changes in the magnetic behaviour of zinc ferrite powders.

\section{Experimental part}

Zinc ferrite nanoparticles were prepared by coprecipitation route using five mixed aqueous solutions of $0.2 \mathrm{M}$ $\mathrm{ZnCl}_{2}$ and $0.4 \mathrm{FeCl}_{3} \cdot 6 \mathrm{H}_{2} \mathrm{O}$, following the synthesis protocol described in [49]. The obtained samples are noted in this manuscript as $\mathrm{ZFO} \mathrm{nM}$, where $\mathrm{n}=1 \div 5$.

\section{Characterization}

Crystal phase formation of the annealed samples was checked by powder X-ray Diffraction (XRD) using the X-ray diffractometer type X'Pert Pro MPD diffractometer by PANalytical B. V. with $\mathrm{Cu} \mathrm{K}_{\alpha}$ radiation, $\lambda=0.15406 \mathrm{~nm}$. The

\footnotetext{
*email: gafton.vasilica@gmail.com
} 
particle size, chemical composition and external morphology of the fine annealed powders were characterized by transmission electron microscope (TEM JEOL JEM-2010). Fourier-transform infrared (FT-IR) spectra of the powders (as pellets in $\mathrm{KBr}$ ) were recorded in the range $4000-400 \mathrm{~cm}^{-1}$ with a resolution of $4 \mathrm{~cm}^{-1}$ using a FTIR Spectrometer (Jasco 660 Plus). Magnetic measurements were performed at room temperature using a vibrating sample magnetometer system (Model VSM 3900 Princeton). The saturation magnetization values were determined by the interception methods in $\mathrm{M}=\mathrm{f}(1 / \mathrm{H})$ graphical representation.

\section{Results and discussions}

$X$-Ray diffraction analysis

The X-Ray diffraction patterns at room temperature for annealed powders synthesized at different concentration values of $\mathrm{NaOH}$ solution are given in Figure 1.

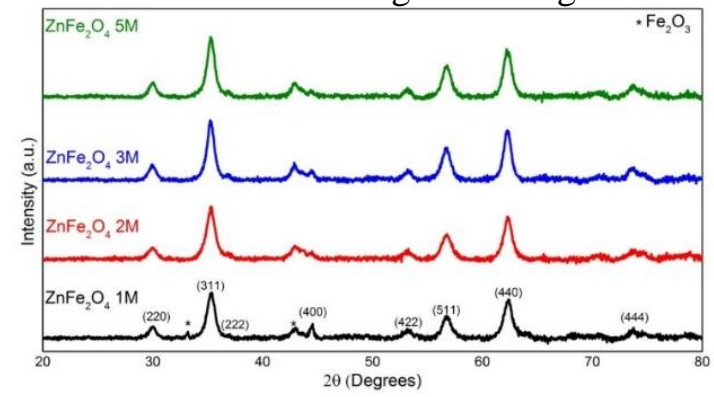

Fig. 1 X-Ray patterns of ZFO nM powders annealed at $500^{\circ} \mathrm{C}$

All annealed samples exhibit Bragg reflections peaks perfectly indexed to the cubic spinel structure (Fd-3m) indicating the formation of the single-phase $\mathrm{ZnFe}_{2} \mathrm{O}_{4}$ spinel ferrites [35, 49], but a slight contribution appears at the lowest $\mathrm{NaOH}$ concentration corresponding to an impurity phase such as $\mathrm{Fe}_{2} \mathrm{O}_{3}$, which dominates over (400) plane once the concentration is increased. XRD patterns show broad peaks due to small crystallite size. The diffraction patterns for all samples have been analysed and the results are listed in Table 1.

Table 1

THE CORRESPONDING REFINED VALUES OF THE LATTICE PARAMETERS AND CRYSTALLITE SIZES, VIBRATIONAL FREQUENCY OF Me-O BONDS: $v_{1}$ FOR MTh - O AND $v_{2}$ for Moh $-O$ AND CORRESPONDING $\mathrm{K}_{\mathrm{A}}, \mathrm{K}_{\mathrm{B}}$ FORCE CONSTANTS OF ZFO nM SAMPLES

\begin{tabular}{|c|c|c|c|c|c|c|c|}
\hline $\begin{array}{l}\mathrm{NaOH} \\
\text { concentration }\end{array}$ & $\begin{array}{l}\text { Lattice } \\
\text { constant, } \\
a[\mathrm{~A}]\end{array}$ & $\begin{array}{l}\text { Crystallite size, } \\
D_{X R D}[\mathrm{~nm}]\end{array}$ & $\begin{array}{l}\text { Particle size, } \\
D_{T E M}[\mathrm{~nm}]\end{array}$ & $\begin{array}{l}v_{1} \\
\left(\mathbf{c m}^{-1}\right)\end{array}$ & $\begin{array}{l}v_{2} \\
\left(\mathrm{~cm}^{-1}\right)\end{array}$ & $\begin{array}{l}\mathbf{k}_{\mathrm{A}}\left(\text { dyne } / \mathrm{cm}^{2}\right) \\
\times 10^{4}\end{array}$ & $\begin{array}{l}k_{B}\left(\text { dyne } / \mathrm{cm}^{2}\right) \\
\times 10^{4}\end{array}$ \\
\hline $1 \mathrm{M}$ & 8.43 & 9.2 & 6.6 & 570 & 396 & 13.8 & 5.5 \\
\hline $2 M$ & 8.43 & 8.1 & 9.8 & 571 & 407 & 13.9 & 5.8 \\
\hline $3 M$ & 8.44 & 9.9 & 8.7 & 568 & 397 & 13.7 & 5.5 \\
\hline $4 M$ & 8.43 & 8.9 & 10.2 & 568 & 400 & 13.7 & 5.6 \\
\hline $5 \mathrm{M}$ & 8.43 & 9.3 & 9.4 & 571 & 398 & 13.8 & 5.5 \\
\hline
\end{tabular}

One can observe that samples have an unvarying lattice constant of $8.43 \AA$ and $9 \mathrm{~nm}$ crystallite size, except $3 \mathrm{M}$ sample that has a slightly higher lattice constant of $8.44 \AA$ and $2 \mathrm{M}$ sample that has a lower crystallite size of $8 \mathrm{~nm}$.

\section{Electronic microscopy}

Morphology, agglomeration degree and particles dimension was investigated by TEM technique. Figure 2 shows the TEM micrographs with $20 \mathrm{~nm}$ scale of the zinc nanoferrites synthesized by varying the concentration of $\mathrm{NaOH}$.

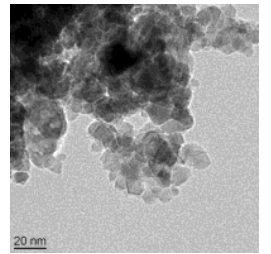

a)ZFO $1 \mathrm{M}$

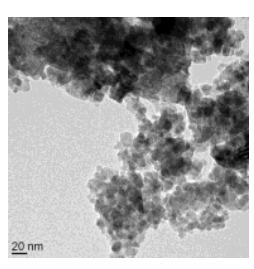

b)ZFO 2M

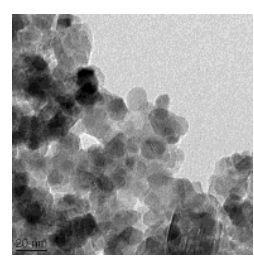

c)ZFO 3M

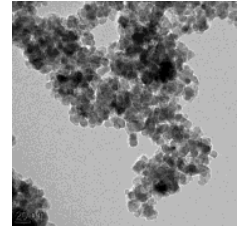

d)ZFO 5M
Fig. 2 TEM images of ZFO a)-d) $\mathrm{nM}$ samples annealed at $500^{\circ} \mathrm{C}$, $\mathrm{n}=1,2,3,5$

One can observe the influence of $\mathrm{NaOH}$ on the synthesis process that leads to different texture and dimensions of the nanoparticles, increasing co-precipitating agent concentration determines a slightly higher grain size, but this increase is not directly proportional with the $\mathrm{NaOH}$ concentration, instead the order is $1 \mathrm{M}<3 \mathrm{M}<5 \mathrm{M}<2 \mathrm{M}<4 \mathrm{M}$. All samples appear strongly agglomerated, cubic facet for $n=1,2$ and almost spherical for $n=3,4,5$. Changing the concentration of $\mathrm{NaOH}$ leads to an average particle size $D_{T E M}$ of $10 \mathrm{~nm}$, except a lower value of $6.6 \mathrm{~nm}$ for $1 \mathrm{M}$ sample. Particle size identified from TEM micrographs are in the same order of nanometres with the crystallite dimensions calculated from XRD patterns. 


\section{FT-IR spectroscopy analysis}

Absorption of surfactant molecules on the surface of zinc nanoferrites is confirmed by FTIR spectra of annealed samples synthesized at different concentration of $\mathrm{NaOH}$ and presented in Figure 3.

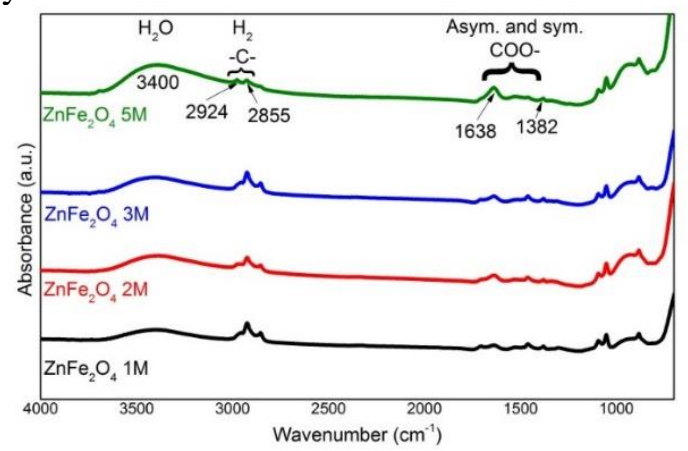

Fig. 3. FTIR spectra of ZFO nM nanoparticles at different concentration of $\mathrm{NaOH}$

The spectra for samples annealed at $500^{\circ} \mathrm{C}$ of $\mathrm{CMC}$ capped zinc ferrite nanoparticles prepared at different concentration of $\mathrm{NaOH}$ solution present strong peaks around $580 \mathrm{~cm}^{-1}$ corresponding to stretching vibrations of Me-O characteristic cubic spinel structure [11, 49]. The two distinct vibrations presented in the spectra at $1382 \mathrm{~cm}^{-1}$ and $1638 \mathrm{~cm}^{-1}$ are attributed to symmetric and asymmetric vibrations of carboxylic group (COO-). The characteristic vibrations at $2855 \mathrm{~cm}^{-1}$ and $2924 \mathrm{~cm}^{-1}$ are assigned to the stretching of asymmetric and symmetric vibrations of methylene group (-CH2-) of carboxymethylcellulose. Additionally, all spectra have one broad band in the range 3400 $\mathrm{cm}^{-1}$ corresponding to $\mathrm{H}_{2} \mathrm{O}$.

In the low domain one can observe peaks corresponding to bonds of metal from tetrahedral and octahedral position with oxygen $\left(\mathrm{M}_{\mathrm{Th}}-\mathrm{O}\right.$ and $\left.\mathrm{M}_{\mathrm{Oh}}-\mathrm{O}\right)$, one at $570 \mathrm{~cm}^{-1}$ corresponding to $\mathrm{Fe}-\mathrm{O}$ and the one corresponding to $\mathrm{Zn}-\mathrm{O}$ at $400 \mathrm{~cm}^{-1}$, with slight variation depending on $\mathrm{nM}$. The reduced force constant for $3 \mathrm{M}$ sample corresponds to an increased lattice constant.

\section{Magnetic measurements}

Magnetizations $(\mathrm{M})$ versus magnetic field $(\mathrm{H})$ hysteresis loop measured for all five samples at room temperature are presented in Figure 4 and the values of the magnetic parameters are listed in Table 2. Zn ferrite, which is a paramagnet at room temperature in bulk form, has been found to have magnetic order at room temperature also by other authors [12,49]. The $S$-shape magnetizations of the hysteresis loops suggest the presence of superparamagnetic clusters. In our case the saturation magnetization $\mathrm{M}_{\mathrm{S}}$ at $10 \mathrm{kOe}\left(\mathrm{M}_{\mathrm{s}}\right)$ was found to be $20.52 \mathrm{emu} / \mathrm{g}$ with negligible coercivity $\left(\mathrm{H}_{\mathrm{C}}\right)$ and remanence. The non-saturation of the $\mathrm{M}(\mathrm{H})$ loop and the absence of the remanent magnetization $\mathrm{M}_{\mathrm{R}}$ and coercivity are indicative of the presence of superparamagnetic and single domain crystals

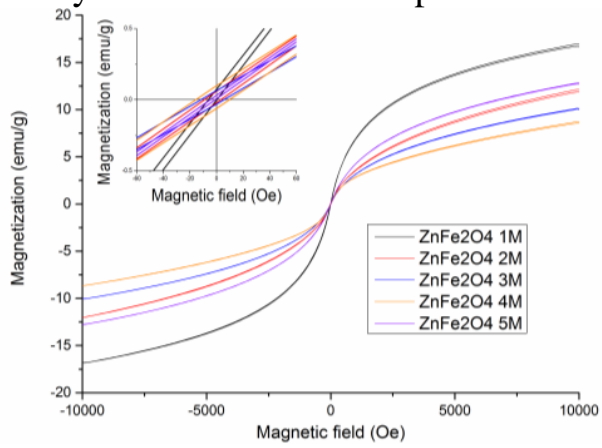

Fig. $4 \mathrm{M}(\mathrm{H})$ loops of ZFO nM nanoparticles at room temperature

At the nanoscale some of the $\mathrm{Zn}^{2+}$ ion is transferred to the octahedral position, which leads to the imbalance in spin configuration, and introduction of large magnetization compared to paramagnetic bulk $\mathrm{ZnFe}_{2} \mathrm{O}_{4}$. Thus, zinc ferrite nanoparticles become a mixed spinel type due to change in cation distribution [7].

Magnetic properties of nanoparticles seem to be influenced by the morphology and average particles size. Increasing the concentration of $\mathrm{NaOH}$ one can observe that remanent magnetization and coercivity values also increase, excepting sample 5M. Simultaneously, the saturation magnetization decrease with increasing the $\mathrm{NaOH}$ concentration, excepting sample 5M because of increase in nanoparticle surface-to-volume ratio [47] and absorption of ligands at the surface of the nanocrystals which affects the electronic and magnetic structures at the surface and thereby impacts on the magnetic properties of the system [48]. A part of sample $4 \mathrm{M}$ has been supplementary investigated after applying a low dose of ion bombardment, as reported in Ref. [49], in order to gain knowledge about the stability of zinc ferrite magnetism.

Table 2

$\mathrm{H}_{\mathrm{c}}(\mathrm{Oe}), \mathrm{M}_{\mathrm{r}}(\mathrm{emu} / \mathrm{g}), \mathrm{M}_{\mathrm{s}}(\mathrm{emu} / \mathrm{g})$ AND K VALUES OF $\mathrm{ZNFE}_{2} \mathrm{O}_{4} \mathrm{NANOPARTICLES}$ AT DIFFERENT CONCENTRATION OF NaOH

\begin{tabular}{|lllllll|}
\hline $\begin{array}{l}\mathrm{NaOH} \\
\text { concentration }\end{array}$ & Sample & $\mathbf{H}_{\mathbf{C}}(\mathrm{Oe})$ & $\mathbf{M}_{\mathbf{r}}(\mathbf{e m u} / \mathrm{g})$ & $\mathbf{M}_{\mathbf{s}}(\mathrm{emu} / \mathrm{g})$ & $\mathbf{M}_{\mathbf{r}} / \mathbf{M}_{\mathbf{s}}$ & $\mathbf{K}$ \\
$\mathbf{1 M}$ & $\mathrm{ZnFe}_{2} \mathbf{O}_{\mathbf{4}} \mathbf{1 M}$ & 3.1688 & 0.3855 & 20.52 & 0.0187 & 67.7 \\
\hline
\end{tabular}




\begin{tabular}{|lllllll|}
\hline $\mathbf{2 M}$ & $\mathbf{Z n F e}_{2} \mathbf{O}_{4} \mathbf{2 M}$ & 6.1905 & 0.0407 & 16.32 & 0.0024 & 105.2 \\
$\mathbf{3 M}$ & $\mathbf{Z n F e}_{2} \mathbf{O}_{4} \mathbf{3 M}$ & 8.6285 & 0.0473 & 13.76 & 0.0034 & 123.6 \\
$\mathbf{4 M}$ & $\mathbf{Z n F e}_{2} \mathbf{O}_{\mathbf{4}} \mathbf{4 M}$ & 12.573 & 0.0795 & 12.15 & 0.0065 & 159.1 \\
$\mathbf{5 M}$ & $\mathbf{Z n F e}_{2} \mathbf{O}_{\mathbf{4}} \mathbf{5 M}$ & 2.778 & 0.0181 & 16.75 & 0.0010 & 48.4 \\
\hline
\end{tabular}

The anisotropy constant was calculated using equation $K=\frac{H_{C} * M_{S}}{0.96}$ and the values are presented in Table 2. One can observe that highest anisotropy constant corresponds to largest particle size $D_{\text {TEM }}$. Agglomeration of nanoparticles observed in TEM micrographs lead to different magnetic behaviour of samples. Shape anisotropy in the form of polyhedral nanoparticles was introduced in samples to study their effect on magnetic properties by decreasing the size of the particles.

The squareness ratio (SQR) of a loop provides the distinction between soft and hard magnetic materials. This is calculated from the equation $S Q R=M_{r} / M_{s}$. Low values of the $S Q R$ and $H_{C}$ were obtained for all the samples that indicate soft magnetic properties of the compounds consisting on small single-domain, randomly oriented assembly of particles.

Considering our previous works and the literature available on this subject, we conclude that no higher $\mathrm{NaOH}$ concentration is required to be an efficient one in controlling the particle size and improving the microstructure.

\section{Conclusions}

In conclusion, nanocrystalline zinc ferrite was successfully synthesized by coprecipitation method changing the condition reactions by varying the concentration of precipitation agent. The cubic spinel phase was confirmed by XRD measurements. The bonding of functional groups from CMC on the surface of nanoparticles was also confirmed by FTIR analysis. The influence of different concentration of $\mathrm{NaOH}$ on the size and on the morphologies was also investigated to find the appropriate parameters of the synthesis. The variations of concentration during the synthesis method are found to be crucial on the structural morphologies of the nanoparticles.

\section{References}

1.YELENICH, O. V. , SOLOPAN, S. O., KOLODIAZHNYI, T. V., DZYUBLYUK V. V., TOVSTOLYTKIN, A. I., BELOUS, A. G., Magnetic properties and high heating efficiency of $\mathrm{ZnFe}_{2} \mathrm{O}_{4}$ nanoparticles, Mater. Chem. Phys., 146 (1-2), 2014, $129-135$.

2.SATTARAHMADY, N., ZARE, A. R., MEHDIZADEH, T., AZARPIRA, H. H., HEIDARI, N., LOTFI, M., Dextrin-coated zinc substituted cobalt-ferrite nanoparticles as an MRI contrast agent: In vitro and in vivo imaging studies, Colloids Surfaces B Biointerfaces, 129, 2015, 15-20.

3.WAN, J. , JIANG, X., LI, H., CHEN, K., Facile synthesis of zinc ferrite nanoparticles as non-lanthanide $\mathrm{T}_{1}$ MRI contrast agents, J. Mater. Chem., 22 (27), 2012, 13500.

4.LIU, J., DENG, M., HUANG, Z., YIN, G., LIAO, X., GU, J., Preparation of $\mathrm{ZnFe}_{2} \mathrm{O}_{4}$ nanoparticles in the template of silk-fibroin peptide and their neuro-cytocompability in PC12 cells, Colloids Surfaces B Biointerfaces, 107, 2013, 19-26.

5.GIRI, J., PRADHAN, P., SOMANI, V., CHELAWAT, H., CHHATRE, S., BANERJEE, R., BAHADUR, D., Synthesis and characterizations of water-based ferrofluids of substituted ferrites $\left[\mathrm{Fe}_{1-\mathrm{x}} \mathrm{B}_{\mathrm{x}} \mathrm{Fe}_{2} \mathrm{O}_{4}, \mathrm{~B}=\mathrm{Mn}\right.$, $\left.\mathrm{Co}(\mathrm{x}=0-1)\right]$ for biomedical applications J. Magn. Magn. Mater., 320, (5), 2008, 724-730.

6.ESMAEILI, A., ALIZADEH HADAD, N., Preparation of $\mathrm{ZnFe}_{2} \mathrm{O}_{4}$ - chitosan-doxorubicin hydrochloride nanoparticles and investigation of their hyperthermic heat-generating characteristics, Ceram. Int., 41 (6), 2015, 7529-7535.

7.HOQUE, S. M., HOSSAIN, M. S., CHOUDHURY, S., AKHTER, S., HYDER, F., Synthesis and characterization of $\mathrm{ZnFe}_{2} \mathrm{O}_{4}$ nanoparticles and its biomedical applications, Mater. Lett., 162 (3), 2016, 60-63.

8.JIA, Z., QIN, Q., LIU, J., SHI, H., ZHANG, X., HU, R., LI, S., ZHU, R., The synthesis of hierarchical $\mathrm{ZnFe}_{2} \mathrm{O}_{4}$ architecture and their application for $\mathrm{Cr}$ (VI) adsorption removal from aqueous solution, Superlattices Microstruct., 82, 2015, 174-187.

9.KALIA, S., KANGO, S., KUMAR, A., HALDORAI, Y., KUMARI, B., KUMAR, R., Magnetic polymer nanocomposites for environmental and biomedical applications, Colloid Polym. Sci., 292 (9), 2014, 2025-2052.

10.ZHANG, J., SONG, J. M., NIU, H. L., MAO, C. J., ZHANG, S. Y., SHEN, Y. H., ZnFe $\mathrm{Zn}_{4}$ nanoparticles: Synthesis, characterization, and enhanced gas sensing property for acetone, Sensors Actuators, B Chem., 221, 2015, 55-62.

11.SINGH, J. P., GAUTAM, S., SRIVASTAVA, R. C., ASOKAN, K., KANJILAL, D., CHAE, K. H., Crystallite size induced crossover from paramagnetism to superparamagnetism in zinc ferrite nanoparticles, Superlattices Microstruct., 86, 2015, 390-394.

12.RAITA, O., POPA, A., TOLOMAN, D., BADILITA, V., PITICESCU, R.R., GIURGIU, L.M., Superparamagnetic behavior of ZnFe $2 \mathrm{O}_{4}$ nanoparticles as evidenced by EPR, J. Optoelectron. Adv. Mater., 17 (9-10), 2015, 1314-1318.

13.LOPEZ-MALDONADO, K. L., DE LA PRESA, P., BETANCOURT, I., FARIAS MANCILLA, J.R., MATUTES AQUINO, J.A., HERNANDO, A., ELIZALDE GALINDO, J.T., Superparamagnetic response of zinc ferrite incrusted nanoparticles, J. Alloys Compd., 637, 2015, 443-448.

14.RODRÍGUEZ TORRES, C. E., PASQUEVICH, G. A., MENDOZA ZELIS, P., GOLMAR, F., HELUANI, S. P., NAYAK, S. K., ADEAGBO, W. A., HERGERT, W., HOFFMANN, M., ERNST, A., ESQUINAZI, P., STEWART, S. J., Oxygen-vacancy-induced local ferromagnetism as a driving mechanism in enhancing the magnetic response of ferrites, Phys. Rev. B - Condens. Matter Mater. Phys., 89 (10), 2014, 1-7.

15.MATHEW, D. S., JUANG, R. S., An overview of the structure and magnetism of spinel ferrite nanoparticles and their synthesis in microemulsions, Chem. Eng. J., 129 (1-3), 2007, 51-65.

16.SINGH, C., JAUHAR, S., KUMAR, V., SINGH, J., SINGHAL, S., Improved visible-light photocatalytic properties of $\mathrm{ZnFe}_{2} \mathrm{O}_{4} \mathrm{Synthesized}$ via sol-gel method combined with a microwave treatment, Mater. Chem. Phys., 156, 2015, 188-197.

17.FENG, J., WANG, Y., ZOU, L., LI, B., HE, X., LIU, S., CHEN, T., FAN, Z., REN, Y., LÜ, Y., Chem. Res. Chinese Univ., 31 (3), 2015 , $439-442$. 
18.MENDONÇA, E. C., JESUS, C. B. R., FOLLY, W. S. D., MENESES, C. T., DUQUE, J. G. S., Size Effects on the Magnetic Properties of $\mathrm{ZnFe}_{2} \mathrm{O}_{4}$ Nanoparticles, J. Supercond. Nov. Magn., 26 (6), 2013, 2329-2331.

19.RAMANA, P. V., RAO, K. S., RAO, K. H., Influence of iron content on the structural and magnetic properties of Ni-Zn ferrite nanoparticles synthesized by PEG assisted sol-gel method, J. Magn. Magn. Mater., 465 (June), 2018, 747-755.

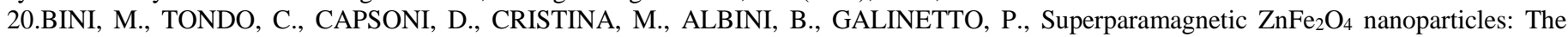
effect of Ca and Gd doping, Mater. Chem. Phys., 204, 2018, 72-82.

21.CHAKRADHARY, V. K., ANSARI, A., AKHTAR, M. J., Design, synthesis, and testing of high coercivity cobalt doped nickel ferrite nanoparticles for magnetic applications, J. Magn. Magn. Mater., 469 (February 2018), 2019, 674-680.

22.STEFANESCU, M., BOZDOG, M., MUNTEAN, C., STEFANESCU, O., VLASE, T., Synthesis and magnetic properties of Co ${ }_{1-\mathrm{x}} \mathrm{Zn}_{\mathrm{x}} \mathrm{Fe}_{2} \mathrm{O}_{4}$ $(\mathrm{x}=0 \div 1)$ nanopowders by thermal decomposition of Co(II), Zn(II) and Fe(III) carboxylates, J. Magn. Magn. Mater., 393, $2015,92-98$.

23.MURUGESAN, C., KAMBHALA, N., ANGAPPANE, S., CHANDRASEKARAN, G., Influence of Zn concentration on the structural and magnetic properties of nanocrystalline $\mathrm{Cu}_{1-\mathrm{x}} \mathrm{Zn}_{\mathrm{x}} \mathrm{Fe}_{2} \mathrm{O}_{4}$ mixed ferrites synthesized using novel combustion method, J. Magn. Magn. Mater., 443, $2017,334-342$.

24.AMIR, M. D., GUNGUNES, H., BAYKAL, A., ALMESSIERE, M. A., SOZERI, H., ERCAN, I., SERTKOL, M., ASIRI, S., MANIKANDAN, A., Effect of annealing temperature on magnetic and Mossbauer properties of $\mathrm{ZnFe}_{2} \mathrm{O}_{4}$ nanoparticles by sol-gel approach, J. Supercond. Nov. Magn., 31, 2018, 3347-3356.

25.DEY, S., MONDAL, R., MAJUMDER, S., DASGUPTA, P., PODDAR, A., BANERJEE, S., KUMAR, S., Superparamagnetic behavior of nanosized $\mathrm{ZnFe}_{2} \mathrm{O}_{4}$, Mater. Today Proc., 5 (3), 2018, 9855-9859.

26.VINOSHA, P. A., XAVIER, B., KRISHNAN, S., DAS, S. J., Investigation on the magnetically separable zn substituted $\mathrm{CoFe}_{2} \mathrm{O}_{4}$ nanoparticles with enhanced photo-fenton degradation, J. Nanosci. Nanotechnol., 2018, 5354-5366.

27.RANI, B. J., YUVAKKUMAR, G. R. R., RAVICHANDRAN, V. G. S., RAJALAKSHMI, M. T. A P., Pure and cobalt-substituted zincferrite magnetic ceramics for supercapacitor applications, Appl. Phys. A, 124 (7), 2018, 1-12.

28.ICHIKAWA, R. U., PARRA, J. P. R. L. L., MARTINS, M. L., YOSHITO, W. K., SAEKI, M. J., TURRILLAS, X., MARTINEZ, L. G., Size-strain analysis of iron-excess $\mathrm{Mn}-\mathrm{Zn}$ ferrite nanoparticles using synchrotron diffraction and its correlation with magnetic saturation and isoelectric pH, J. Nanosci. Nanotechnol., 18 (8), 2018, 5697-5703.

29.MATINISE, N., KAVIYARASU, K., MONGWAKETSI, N., KHAMLICH, S., KOTSEDI, L., MAYEDWA, N., MAAZA, M., Green synthesis of novel zinc iron oxide $\left(\mathrm{ZnFe}_{2} \mathrm{O}_{4}\right)$ nanocomposite via Moringa Oleifera natural extract for electrochemical applications, Appl. Surf. Sci., 446, 2018, 66-73.

30.CIOCARLAN, R. G., SEFTEL, E. M., MERTENS, M., PUI, A., MAZAJ, M., TUSAR, N. N., COOL, P., Novel magnetic nanocomposites containing quaternary ferrites systems $\mathrm{Co}_{0.5} \mathrm{Zn}_{0.25} \mathrm{M}_{0.25} \mathrm{Fe}_{2} \mathrm{O}_{4}(\mathrm{M}=\mathrm{Ni}, \mathrm{Cu}, \mathrm{Mn}, \mathrm{Mg})$ and $\mathrm{TiO}_{2}$-anatase phase as photocatalysts for wastewater remediation under solar light irradiation, Mater. Sci. Eng. B Solid-State Mater. Adv. Technol., 230 (August 2017), $2018,1-7$.

31.CIOCARLAN, R. G., PUI, A., GHERCA, D., VIRLAN, C., DOBROMIR, M., NICA, V., CRAUS, M. L., GOSTIN, I. N., CALTUN, O. F., HEMPELMAN, R., COOL, P., Quaternary $\mathrm{M}_{0.25} \mathrm{Cu}_{0.25} \mathrm{Mg}_{0.5} \mathrm{Fe}_{2} \mathrm{O}_{4}(\mathrm{M}=\mathrm{Ni}, \mathrm{Zn}, \mathrm{Co}, \mathrm{Mn})$ ferrite oxides: Synthesis, characterization and magnetic properties, Mater. Res. Bull., 81, 2016, 63-70.

32.VIRLAN, C., CALTUN, O. F., LUTIC, D., PUI, A., New Bio-surfactant used in the Synthesis of Functionalized Nanoferrites as Potential Catalysts, Curr. Nanosci., 13 (3), 2017, 247-253.

33.GHERCA, D., PUI, A., NICA, V., CALTUN, O., CORNEI, N., Eco-environmental synthesis and characterization of nanophase powders of $\mathrm{Co}, \mathrm{Mg}, \mathrm{Mn}$ and Ni ferrites, Ceram. Int., 40 (7) PART A, 2014, 9599-9607.

34.DANIEL, G., CIOCARLAN, R. G., COZMA, D. G., CORNEI, N., NICA, V., SANDU, I., PUI, A., Influence of surfactant concentration (carboxymethylcellulose) on morphology and particle sizes of cobalt nanoferrites, Rev. Chim., 64 (8), 2013, 3-6.

35.PUI, A., GHERCA, D., CORNEI, N., Synthesis and characterization of $\mathrm{MFe}_{2} \mathrm{O}_{4}(\mathrm{M}=\mathrm{Mg}, \mathrm{Mn}, \mathrm{Ni})$ nanoparticles, Mater. Res. Bull., 48 (4), $2013,1357-1362$.

36.NICA, V., DANIEL, G., URSU, C., TUDORACHE, F., BRINZA, F., PUI, A., Synthesis and Characterization of Co-Substituted Ferrite Nanocomposites, IEEE Trans. Magn., 49 (1), 2013, 26-29.

37..GHERCA, D., CORNEI, N., MENTRÉ, O., KABBOUR, H., DAVIERO-MINAUD, S., PUI, A., In situ surface treatment of nanocrystalline $\mathrm{MFe}_{2} \mathrm{O}_{4}(\mathrm{M}=\mathrm{Co}, \mathrm{Mg}, \mathrm{Mn}, \mathrm{Ni})$ spinel ferrites using linseed oil, Appl. Surf. Sci., 287, 2013, 490-498.

38.GHERCA, D., PUI, A., CORNEI, N., COJOCARIU, A., NICA, V., CALTUN, O., Synthesis, characterization and magnetic properties of $\mathrm{MFe}_{2} \mathrm{O}_{4}(\mathrm{M}=\mathrm{Co}, \mathrm{Mg}, \mathrm{Mn}, \mathrm{Ni})$ nanoparticles using ricin oil as capping agent, J. Magn. Magn. Mater., 324 (22), $2012,3906-3911$.

39.PUI, A., GHERCA, D., CARJA, G., Characterization and magnetic properties of capped $\mathrm{CoFe}_{2} \mathrm{O}_{4}$ nanoparticles ferrite prepared in carboxymethylcelullose solution, Dig. J. Nanomater. Biostructures, 6 (4), 2011, 1783-1791.

40.VIRLAN, C., TUDORACHE, F., PUI, A., Increased sensibility of mixed ferrite humidity sensors by subsequent heat treatment, Int. J. Appl. Ceram. Technol., 14 (6), 2017, 1174-1182.

41.KANT SHARMA, R., GHOSE, R., Synthesis and characterization of nanocrystalline zinc ferrite spinel powders by homogeneous precipitation method, Ceram. Int., 41 (10), 2015, 14684-14691.

42.POURBAFARANI, S., The effect of alkali concentration on the structural and magnetic properties of Mn-ferrite nanoparticles prepared via the coprecipitation method, Metall. Mater. Trans. A, 45 (10), 2014, 4535-4537.

43.SINGH, S., KUMAR, N., JHA, A., SAHNI, M., BHARGAVA, R., CHAWLA, A., CHANDRA, R., KUMAR, S., CHAUBEY, S., Effect of annealing temperature on the physical properties of Zn-ferrite nanoparticles, J. Supercond. Nov. Magn., 27 (3), 2014, $821-826$.

44.CHAUDHARI, P. R., GAIKWAD, V. M., ACHARYA, S. A., Role of mode of heating on the synthesis of nanocrystalline zinc ferrite, Appl. Nanosci., 5 (6), 2015, 711-717.

45.KOLEVA, K. V., VELINOV, N. I., TSONCHEVA, T. S., MITOV, I. G., KUNEV, B. N., Preparation, structure and catalytic properties of $\mathrm{ZnFe}_{2} \mathrm{O}_{4}$, Bulg. Chem. Commun., 45 (4), 2013, 434-439.

46.SORESCU, M., DIAMANDESCU, L., TARABASANU-MIHAILA, D., TEODORESCU, V., Sequence of phases in the hydrothermal synthesis of zinc-doped magnetite system, Mater. Chem. Phys., 106 (2-3), 2007, 273-278.

47.KUMAR, E. R., JAYAPRAKASH, R., Effect of combustion rate and annealing temperature on structural and magnetic properties of manganese substituted nickel and zinc ferrites, J. Magn. Magn. Mater., 348 (86), 2013, 93-100.

48.WU, N., FU, L., SU, M., ASLAM, M., WONG, K. C., DRAVID, V. P., Interaction of Fatty Acid Monolayers with Cobalt Nanoparticles, Nano Letters, 4 (2), 2004, 383-386.

49.TRANDAFIR, E.V., CALTUN, O.F., CIOCARlAN, R., PUI, A., HEMPELMANN, R., DIAMANDESCU, L., CERVERA, S., TRASSINELLI, M., VERNHET, D., Effect of slow charged $90 \mathrm{keV} \mathrm{Ne} \mathrm{e}^{8+}$ ions on zinc ferrite nanoparticles, Materials Research Express, 6 (9), 2019, 095077, https://doi.org/10.1088/2053-1591/ab3174

Manuscript received: 2.10 .2018 